> as scientists sought to explain how development might be linked to chromosomes and heredity, as outlined in studies by Theodor Boveri and Walter Sutton. Further research by embryologist Hans Spemann and others probed how tissues form and what drives cells to develop into different kinds. In recent decades, researchers have been able to genetically modify organisms, track developmental fate and sequence DNA to find naturally occurring variants (insertions, deletions and even single-base-pair mutations) that affect embryo development in flies, fish, frogs, worms, mice and even humans.

Findings in embryology led to a transformation in reproductive medicine with the advent of IVF through the work of Patrick Steptoe and Robert Edwards in 1978. With that came a new focus on the value of human life, from the earliest stages and throughout pregnancy. Concerns burgeoned, leading in the United States to the Dickey-Wicker Amendment of 1996, which prohibited the use of federal funds for research that would create or destroy human embryos. Controversies intensified around cloning technology, beginning in 1997 with the work of Ian Wilmut and his team on Dolly the sheep, and continuing in debates on the ethics of research into human embryonic stem cells and their potential in cell-based therapies for regenerative medicine.

Embryos Under the Microscope does have gaps. It lacks material regarding epigenetic reprogramming - the establishment of DNA and histone-protein modifications in the early embryo that allows embryonic cells with identical DNA sequences to generate diverse cell types - which is a central event in embryology. Yet Maienschein covers broad territory with surprising depth and concision. It seems unlikely that a more readable text will soon emerge to illuminate the journey from theory to observation to ethical considerations in this exciting science.

Lines from T. S. Eliot's 1942 poem Little Gidding from Four Quartets resonate here: "And the end of all our exploring/ Will be to arrive where we started/And know the place for the first time." We have made remarkable progress in our wonderful journey to understand the origins of our development.

Renee Reijo Pera is vice-president for research and economic development at Montana State University in Bozeman, and a professor in the departments of cell biology and neurosciences, and of chemistry and biochemistry. e-mail: renee.reijopera@montana.edu

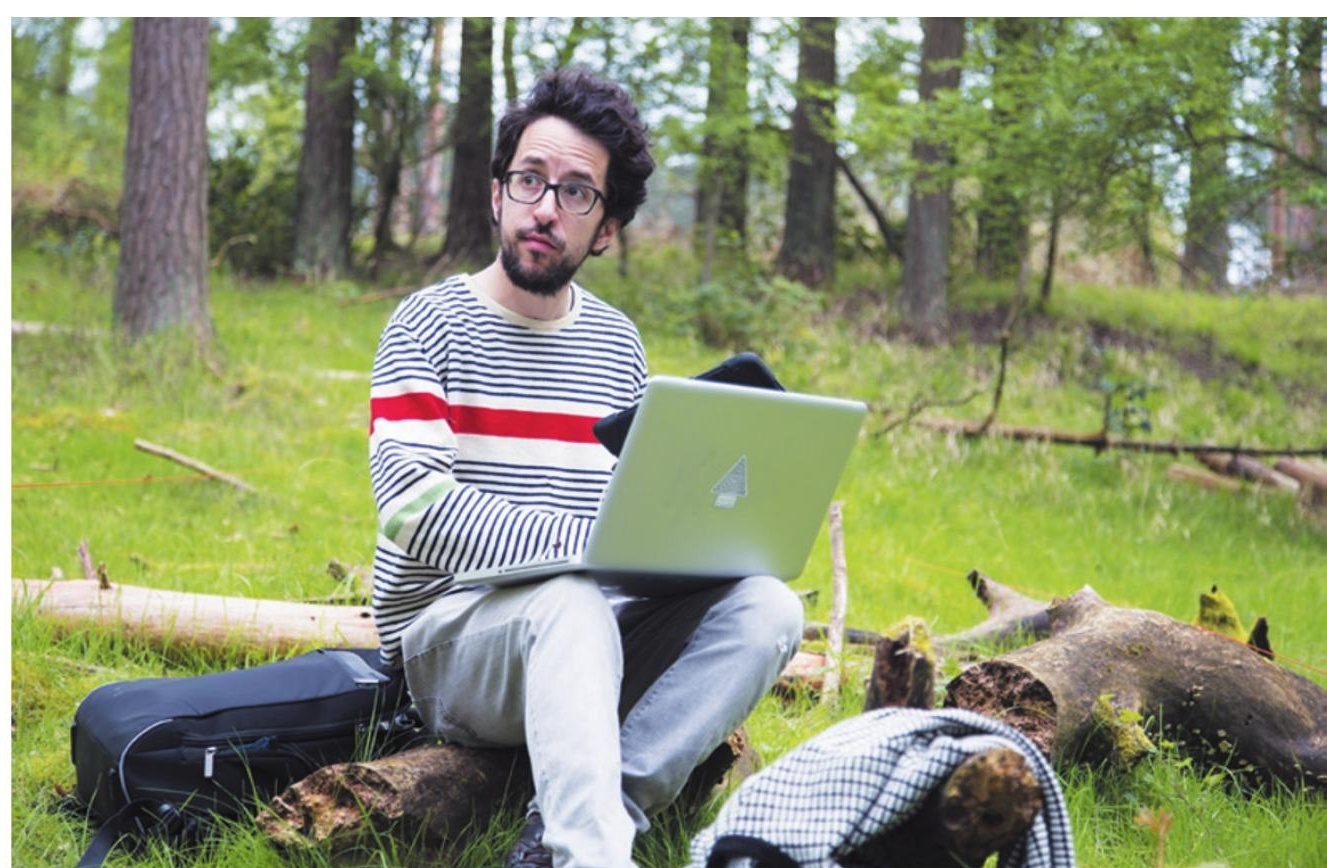

Daniel Jones in Thetford Forest, UK, the first location for his installation Living Symphonies.

Q\&A Daniel Jones

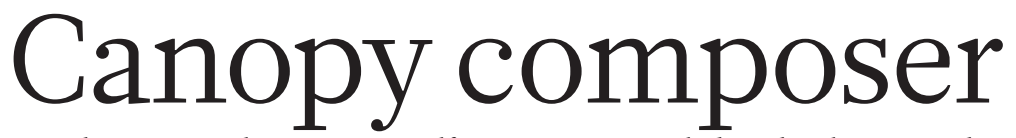

Sound artist Daniel Jones creates self-generating artworks based on human and natural patterns and processes. As he prepares to travel through four UK forests with the installation Living Symphonies, a collaboration with artist James Bulley, he talks about music that emerges from ecosystem dynamics, and works inspired by bacterial genetics and social networks.

\section{What is Living Symphonies?}

It is an ever-changing piece of music that grows in the same way as a forest ecosystem, from the interactions of countless tiny elements. Each reflects the activity of an individual organism, ranging from moss and fungi to deer and birds of prey. The outcome is an organic, emergent symphony comprised of thousands of musical motifs, each portraying a different aspect of the ecosystem.

\section{How do you build each forest installation?}

We start with a survey of the animals and plants. We add behavioural insights from ecologists: what times of day is a blackbird active and foraging, how does it move, what are its preferred food sources? We feed this information into a computer model of the ecosystem (programmed in $\mathrm{C}++$ with the Cinder visualization library) that simulates the second-by-second interactions between Living Symphonies species. This model DANIEL JONES AND is linked to a custom piece of audio software that orchestrates music in real time from a vast
JAMES BULLEY

Next at Thetford Forest 24-30 May 2014. www.livingsymphonies. com array of motifs representing each species. The music is played through a network of speakers in the canopy and undergrowth.

\section{How does the composition sound?}

The motifs for each organism are drawn from fragments that we composed and recorded with orchestral musicians. Our goal is a work with such a great number of interdependent elements, in a nearly infinite combinatorial space, that even we are surprised by the patterns and permutations that arise. This 'emergent' approach runs through all of my work. Emergent phenomena pervade economics, ecology, linguistics and neuroscience; examples include the flocking of birds, and the interactions of neurons that give rise to cognition. By translating the dynamics of a forest ecosystem into music, Living Symphonies aims to heighten awareness of the adaptive and often creative behaviours of these complex systems.

Have any animals responded to the piece? When we ran our first forest prototype last autumn, there was some worry that it would scare off the wildlife. Yet when we 
activated the speakers high in the trees, we were surprised to find that inquisitive wrens appeared, seemingly chirping along. We hope that the effects on wildlife are transient; each installation should be brief enough to have no lasting impact.

\section{You have also created an installation about} the weather. How does that work?

Variable 4 is an eight-speaker outdoor installation that translates weather conditions into musical patterns. It uses sensors to track temperature, humidity, wind, rain and sun. The weather acts as a kind of virtual conductor, with custom software using real-time data to generate harmonic structures. The installation has toured UK locations selected for their wild and unpredictable weather, including Dungeness in Kent, which has been designated a Site of Special Scientific Interest for its unusual geology and ecology. The next edition of Variable 4 can be heard from 5 to 14 September in Portland, Dorset.

\section{What about your work with genetic transfer} in bacteria?

That came out of time I spent with computational biologists at the National Institute for Medical Research in London. They were investigating how bacteria swap genetic information with their neighbours through a mechanism called plasmid exchange. In my 2011 installation Horizontal Transmission, sounds in the gallery are detected by a microphone and transformed into 'sonic chromosomes', which are assimilated into the behaviour of a virtual bacterial population. Visitors can navigate through the population using a three-dimensional control interface, exploring cellular dynamics and communication patterns.

\section{How has Twitter inspired you?}

The Listening Machine was a collaboration with cellist Peter Gregson, created with the Britten Sinfonia chamber orchestra. At its heart was an automated system that continuously generated music based on the real-time activity of a few hundred UK Twitter users. Linguistic software analysed their tweets for sentiment, rhythms of speech and subject matter, and translated them into musical patterns using orchestral fragments representing, for example, phonemes - distinct units of pronunciation. The resultant composition could be heard live through any web-connected device. It ran for nine months starting in May 2012, with a daily rhythm that reflected the real rhythms in a communicating society: peaks of musical density at rush hour and sparse, reflective periods late at night.

\section{Books in brief}

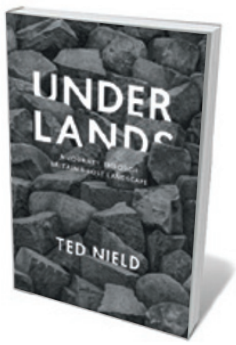

Underlands: A Journey Through Britain's Lost Landscape

Ted Nield GranTA BoOKS (2014)

"We must get under the skin of the land" to understand a country, avers geologist Ted Nield. In this magisterial homage to Britain's geology - once the bedrock of mining industries that enriched the country's coffers and culture - Nield extracts a wealth of stories from the stones. Around broad areas such as geological formation, quarrying and stone-working, he layers a narrative that mixes memoir, science and industrial history. Studded with delights, such as the discovery of basalt's volcanic origin by eighteenth-century 'rogue' Rudolph Erich Raspe - author of the Baron Munchausen tales.

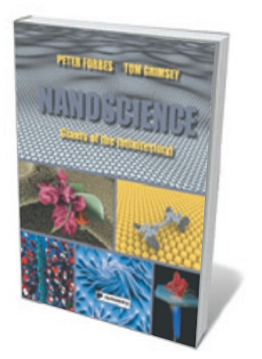

Nanoscience: Giants of the Infinitesimal

Peter Forbes and Tom Grimsey PAPADAKIS (2014)

Lucid text and visuals combine to dazzling effect in this introduction to nanotechnology by science writer Peter Forbes and sculptor Tom Grimsey. The field's godfather, they remind us, was physicist Richard Feynman, whose seminal 1959 lecture 'There's Plenty of Room at the Bottom' posited the idea of engineering at the molecular scale. The authors tour the evolution of the discipline, from studies tracing how components self-organize, to nanomaterials such as graphene and aquaplastics (polymers that are $97 \%$ water), nano-templated stem cells, quasicrystals and much more.

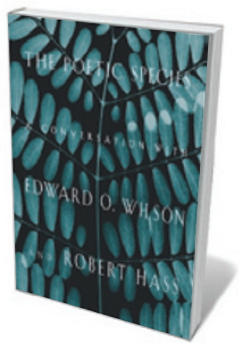

The Poetic Species: A Conversation with Edward O. Wilson and Robert Hass

BELLEVUE LITERARY PRESS (2014)

The principle of consilience, or the unity of knowledge, infuses this conversation between biologist E. O. Wilson and poet Robert Hass, organized by New York institutions the American Museum of Natural History and Poets House. The eminent duo explore echoes and parallels in their respective fields with eloquent concision, from Wilson's advice to poets ("Colonize science") to Hass's musings on the interplay of selfish gene and social imperative in imagination.

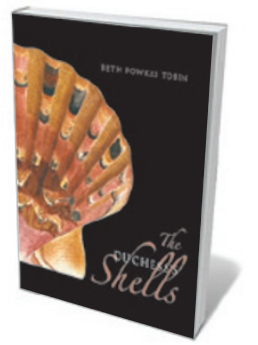

The Duchess's Shells: Natural History Collecting in the Age of Cook's Voyages

Beth Fowkes Tobin YALE UNIVERSITY PRESS (2014)

How do you study a long-dispersed collection? Scholar Beth Fowkes Tobin faced this curious challenge when delving into the story of eighteenth-century conchologist Margaret Cavendish Bentinck, duchess of Portland. Bentinck's shell collection was the era's largest, yet she died before completing her scientific catalogue, and the lot was sold off. Tobin's feat of historical retrieval reveals the duchess as a field collector generous with funds and findings, preventing yet another 'burial at sea' of a historically important female scientist.

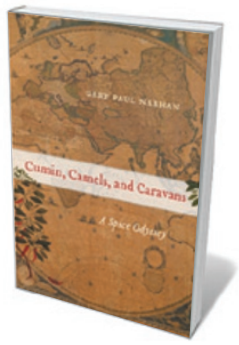

Cumin, Camels, and Caravans: A Spice Odyssey

Gary Paul Nabhan UNIVERSITY OF CALIFORNIA PRESS (2014)

Globalization began not with Christopher Columbus in 1492, as many suggest, but with unknown Arabic and Jewish spice traders centuries before. So argues agricultural ecologist Gary Paul Nabhan in this heady historical and cultural study of ancient trade routes including the Silk Road, the 'information highways' of old. Centring his discussion on commodities such as frankincense, Nabhan adds pungent pinches of botany and gastronomy, such as a 3,700-yearold recipe incorporating lamb, yogurt, cumin and blood. Barbara Kiser 